\title{
AKULTURASI BUDAYA ISLAM DAN JAWA: Ruang Komunal pada Budaya Nyadran Dukuh Krajan, Desa Kromengan, Kabupaten Malang
}

\author{
Sri Winarni, Galih Widjil Pangarsa ${ }^{2}$, Antarißssa ${ }^{3}$, dan Lisa Dwi Wulandari ${ }^{4}$ \\ Mahasiswa Pasca Sarjana Arsitektur Lingkungan Binaan Universitas Brawijaya ${ }^{1}$ \\ Staf Pengajar Program Magister dan Doktor, Universitas Brawijaya ${ }^{234}$ \\ Telp: 08125278832 \\ email:wi2n_mlg27@yahoo.com
}

\begin{abstract}
Javanese and Islamic acculturations adhere to the people living at Dukuh Krajan. Javanese social and cultural aspects affect the spirit of Islamic activities. This is obvious by the use of Javanese/Islamic calendar system in every ritual. Yet, the high value of togetherness and communality is decreasing. This change will result in abandoning culture and growing social problem. It also influences the change of common space in the neighborhood. Therefore, it needs exploration on communal space established through Nyadran ritual. The purpose is to maintain the existence of the communal space as well as to develop togetherness and communality for the next generation. The study employs qualitative design with rationalistic approach. The data were collected through observation and interview. The communal space is formed by the activity, the physical area, the doers and the ritual time. The use of communal space in Nyadran ritual reflects togetherness and mutual cooperation value established as the result of the sense of care and the social awareness to share spaces for public interest.
\end{abstract}

Akulturasi budaya Islam dan Jawa masih melekat pada kehidupan masyarakat Dukuh Krajan. Kegiatan Islam suasananya dipengaruhi oleh aspek budaya dan sosial Jawa. Tergambar jelas pada pemakaian kalender Jawa/Islam pada setiap kegiatan budaya. Namun, nilai-nilai kebersamaan dan kegotongroyangan dalam kegiatan sosial budaya saat ini semakin berkurang. Perubahan ini akan berpengaruh terhadap beberapa budaya setempat yang tersisihkan, dan masalahmasalah sosial yang mulai berkembang. Dampaknya akan berpengaruh juga 
terhadap perubahan mang-ruang komunal di lingkungan pedesaan. Untuk itu perlu diteliti lebih detail tentang ruang komunal yang terbentuk, khususnya pada runtutan kegiatan budaya nyadran. Tujuannya agar ruang komunal yang terbentuk pada tradisi nyadran eksistensinya tetap ada dan terjaga dengan baik serta dapat bermanfaat dalam menumbuhkan dan mengembangkan rasa kebersamaan dan kegotongroyongan pada generasi berikutnya. Penelitian ini menggunakan metode kualitatif dengan pendekatan rasionalistik dengan data dari observasi lapangan dan wawancara. Pembentukan ruang komunal dipengaruhi aktivitas itu sendiri, fisik ruang, pelaku dan waktu kegiatan itu berlangsung. Penggunaan ruang komunal pada kegiatan budaya nyadran mempunyai makna kebersamaan dan keguyuban, yang terbentuk dari kepedulian yang tinggi terhadap lingkungan, serta kesadaran masyarakat dalam memberikan sebagian ruang miliknya yang bermanfaat untuk kepentingan umum.

Keywords: acculturation nyadran ritual, communal space

\section{Pendahuluan}

Masyarakat Dukuh Krajan merupakan masyarakat pedesaan yang berada di wilayah Desa Kromengan, tepatnya berada di sebelah barat Kabupaten Malang. Masyarakat pedesaan memiliki corak kehidupan yang bersifat agraris dengan menggantungkan pada sistem mata pencaharian, pertanian, perkebunan dan lain sebagainya. Masyarakat pedesaan merupakan suatu keguyuban atau gemeinschaft yang memiliki unsur gotong royong yang kuat serta ikatan kekeluargaan yang erat (Bintarto,1989:12-15).

Nilai kebersamaan dan kegotongroyongan dalam kehidupan sosial budaya masyarakat desa saat ini semakin berkurang. Perubahan ini akan berpengaruh terhadap beberapa budaya setempat yang tersisihkan, masalahmasalah sosial yang mulai berkembang seperti gaya hidup materialisme, individualisme, pragamatisme (menguntungkan), hedonisme (kenikmatan sesaat), konsumerisme (lebih senang memakai dari pada membuat), serta semakin memudarnya nilai-nilai keagamaan dalam kehidupan bermasyarakat, berbangsa dan bernegara karena dianggap tidak ada hubungannya (sekulerisme) (Adipawira, 2011: 87).

Dampak dari perubahan sosial budaya saat ini akan berpengaruh juga terhadap perubahan ruang-ruang komunal di lingkungan pedesaan. Ruang bersama atau komunal terwujud sebagai ruang yang bermanfaat untuk kepentingan bersama yang diakui sebagai anggota pemiliknya. Pelaku ruang komunal mempunyai rasa dalam memiliki ruang, rasa dalam menjalin dan membentuk hubungan kekeluargaan dengan sesama, hubungan darah (kerabat) 
dan hubungan sosial.

Penelitian ini mengambil lokasi di permukiman Desa Kromengan, Kabupaten Malang, khususnya wilayah Dukuh Krajan RW. 05, 06 dan 07. Permukiman pedesaan Dukuh Krajan ini merupakan permukiman yang masih memiliki akulturasi budaya Islam Jawa yang melekat pada masyarakatnya dan telah diwariskan secara turun temurun dari generasi ke generasi. Penelitian ini akan membahas lebih detail tentang ruang komunal yang terbentuk pada runtutan kegiatan budaya nyadran. Tujuannya agar ruang komunal yang terbentuk pada tradisi nyadran eksistensinya tetap ada dan terjaga dengan baik serta dapat bermanfaat dalam menumbuhkan dan mengembangkan rasa kebersamaan dan kegotongroyongan pada generasi berikutnya.

Batasan wilayah penelitian Dukuh Krajan ini hanya mencakup wilayah RW. 05, 06, dan 07 dengan alasan bahwa lokasi tersebut merupakan pemusatan aktivitas warga Dukuh Krajan. Pusat pemerintahan tingkat kecamatan, pusat pemerintahan tingkat Desa (kantor Desa), pusat perdagangan yang berupa pasar tingkat kecamatan.

\section{Metode Penelitian}

Metode penelitian yang digunakan adalah metode penelitian kualitatif dengan pendekatan rasionalistik. Data-data yang diperoleh berupa sumber primer yang diawali dengan tahap pengumpulan data dan fakta dengan mengamati dan menyerap berbagai kegiatan yang ada di lokasi penelitian, untuk selanjutnya dapat diolah dan dianalisis. Penjabaran dari kondisi eksisting terutama dari berbagai aspek pembentuk permukiman serta menganalisis berbagai faktor yang ada di balik kegiatan tersebut.

\section{Analisis dan Pembahasan}

Tradisi nyadran merupakan simbol adanya hubungan dengan para leluhur, sesama, dan Yang Mahakuasa atas segalanya. Nyadran merupakan sebuah pola ritual yang mencampurkan budaya lokal dan nilai-nilai Islam, sehingga sangat tampak adanya lokalitas yang masih kental dengan nuansa islami. Bagi masyarakat Jawa, kegiatan tahunan yang bernama nyadran atau sadranan merupakan ungkapan refleksi sosial keagamaan. Nyadran dilakukan untuk berziarah ke makam para leluhur, dan merupakan bentuk pelestarian warisan tradisi serta budaya para nenek moyang. Nyadran dengan ziarah kubur merupakan dua ekspresi kultural keagamaan yang memiliki kesamaan dalam ritus dan objeknya. Perbedaannya hanya terletak pada pelaksanaannya, dimana 
nyadran biasanya ditentukan waktunya oleh pihak yang memiliki otoritas di daerah, dan pelaksanaannya dilakukan secara kolektif (De-kill, 2009: 91).

Desa Kromengan merupakan permukiman pedesaan yang berada di lereng Gunung Kawi sebelah selatan, tepatnya di Kecamatan Kromengan, Kabupaten Malang (RPJMD, 2010-2014). Berdasarkan hasil wawancara dan cerita para tokoh masyarakat setempat, pada jaman dahulu, desa ini berdiri kurang lebih tiga abad yang lalu, sekitar tahun 1700. Pada waktu itu, wilayah Desa Kromengan masih berbentuk hutan belantara yang tidak berpenghuni. Kemudian datanglah suatu rombongan yang terdiri dari lima saudara dan cantrik yang berasal dari kerajaan Mataram Jawa Tengah, yang melakukan babat alas di wilayah tersebut, sehingga terbentuklah suatu perkampungan atau pedesaan. Setelah kedatangannya, mereka berpencar ke wilayah yang berbeda-beda. Ada tiga saudara yang menetap di Desa Kromengan, yang tetap tinggal dan membangun desa, hingga keturunan-keturunannya terus membangun dan mengembangkan desa sampai menjadi seperti kondisi desa yang sekarang ini.

Gambar 1. Peta Kawasan Desa Kromengan

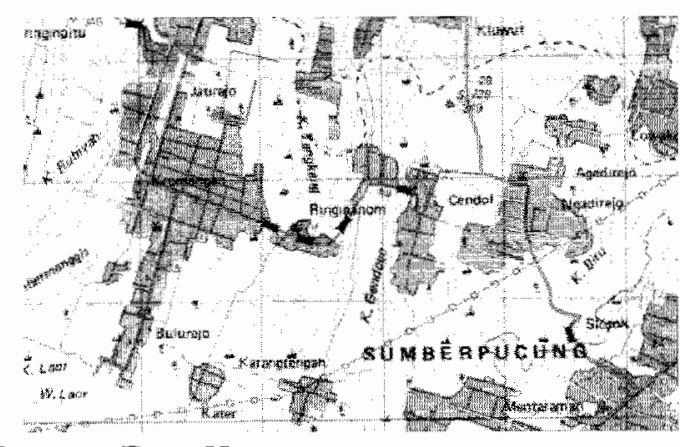

Sumber: TNI AD Jakarta 1988

Akulturasi budaya Islam dan Jawa yang terlihat di masyarakat Dukuh Krajan, contohnya pada kegiatan budaya seperti budaya nyadran, nikahan, slametan, tahlilan, sayan, mithoni dan lain-lain. Permukiman Desa Kromengan dikelilingi area persawahan, dan perkebunan. Permukiman Desa Kromengan terbagi menjadi tiga (3) wilayah: Dukuh Ringinanom, Dukuh Krajan, Dukuh Baloan. Dari masing-masing pedukuhan, Dukuh Krajan merupakan pusat pemerintahan desa, pusat pemerintahan kecamatan dan pusat perekonomian, karakteristik Dukuh Krajan memiliki ciri khas yang cukup bisa mewakili dari keseluruhan pedukuhan yang ada di Dukuh Krajan, lihat Gambar 2. 


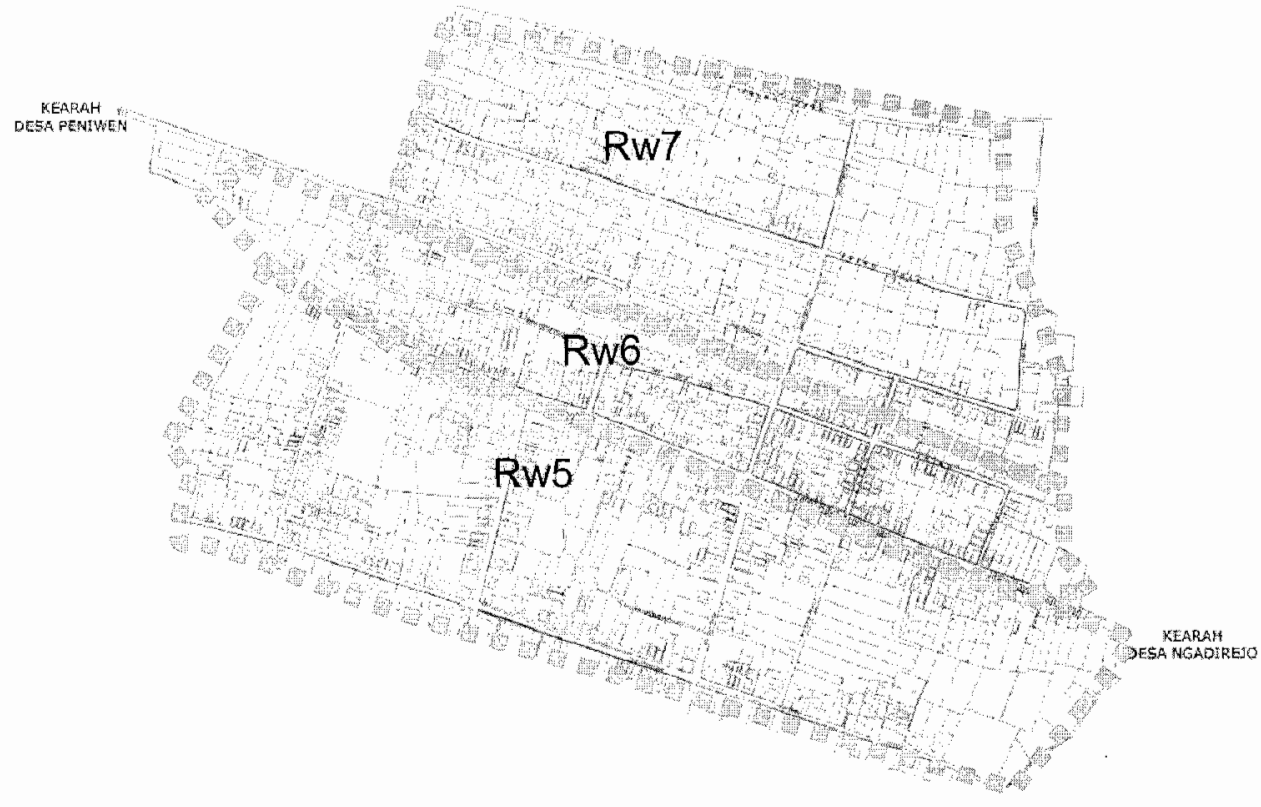

Gambar 2. Peta Lokasi Dukuh Krajan RW. 05, 06 dan 07

Sumber: KPP Pratama Kepanjen, 2008

\section{Budaya Masyarakat Dukuh Krajan}

Budaya yang dimiliki masyarakat Dukuh Krajan salah satunya adalah budaya nyadran, yang kegiatan budayanya berkaitan dengan kalender Jawa/ Islam. Budaya nyadran di Dukuh Krajan memiliki runtutan kegiatan yang sangat padat. Kegiatan budaya nyadran ini dilakukan setiap setahun sekali di bulan Suro. Adapun prosesi tradisi budaya nyadran adalah sebagai berikut:

\section{Kerja Bakti (bersih Desa)}

Runtutan budaya nyadran yang pertama kali yaitu melakukan kegiatan kerja bakti, kegiatan ini dilakukan semua warga Desa Kromengan. Kerja bakti yang dilakukan warga di berbagai wilayah antara lain membersihkan makam, jalan-jalan desa baik jalan utama maupun jalan sawah serta saluran-saluran di lingkungan desa. Kegiatan ini banyak dilakukan oleh bapak-bapak dan anak-anak remaja, para ibu hanya menyiapkan makanan dan minuman yang di letakkan di halaman dekat dengan pagar rumah, lihat Gambar 3. 

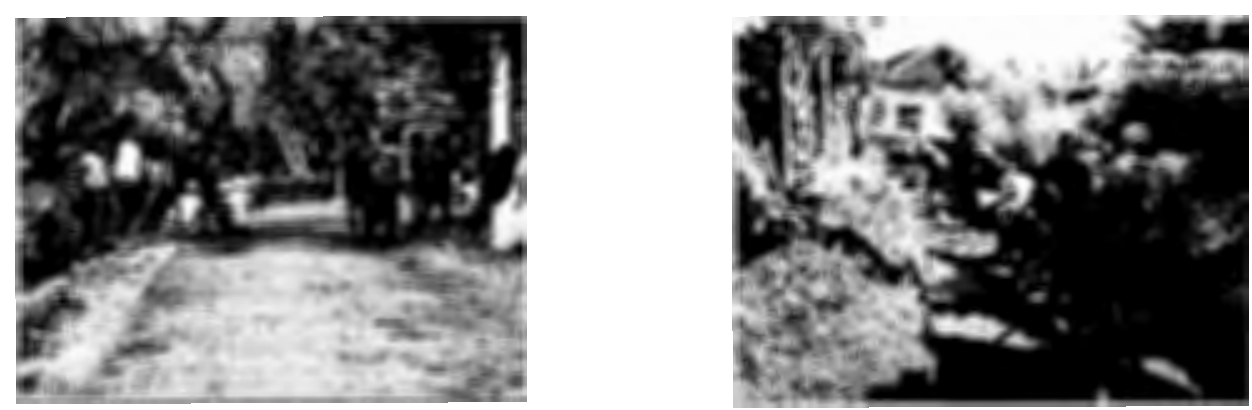

Gambar 3. Kegiatan bersih Desa di jalan menuju makam Sumber: Dokumentasi pribadi, 2011

Aktivitas bersih desa (kerja bakti) dilakukan untuk menciptakan lingkungan pedukuhan menjadi indah bersih dan rapi, kebersamaan sangat terasa di saat kegiatan ini berlangsung. Dalam karakteristik ruang menurut kondisi dan fungsinya (Robinson, 2001: 125), fasilitas jalan bersifat publik, seperti gambar 3 di atas, pada saat kegiatan kerja bakti berlangsung, jalan, makam dan lingkungan desa bersifat publik bagi warga Kromengan, namun tidak bersifat publik bagi warga luar Kromengan. Masyarakat Dukuh Krajan menerima dengan baik pendatang atau tamu yang ingin mengikuti kegiatan ini dengan keramahtamahan dan rasa teposeliro tercermin yang baik selama tidak ada gangguan serta tidak menimbulkan masalah, warga Dukuh Krajan menerima pendatang dengan tangan terbuka.

\section{Kegiatan Nyadran.}

Runtutan yang kedua adalah budaya nyadran sendiri, yaitu dengan melakukan selamatan Desa di Punden para pendiri desa atau leluhur. Menurut hasil wawancara, pada masa lalu persiapan selamatan nyadran Dukuh Krajan Desa Kromengan dilakukan di kediaman rumah mantan kepala Desa, dikarenakan pada zaman dahulu kantor kelurahan belum mempunyai pendopo, sehingga kegiatan masyarakat yang berhubungan dengan perkumpulan sering dilaksanakan di rumah mantan kepala desa. Bentuk rumah tradisional masyarakat Kromengan yang memiliki penambahan bentuk berupa pendopo, di manfaatkan sebagai tempat tradisi hajatan kemasyarakatan.

Budaya nyadran saat ini pelaksanaan dengan melakukan selamatan di Punden Desa yang dihadiri perangkat Desa, sesepuh Desa, ketua RT/ RW, kegiatan terbagi menjadi dua, kegiatan di rumah kepala Desa dengan membuat jenang/dodol untuk cawisan/suguhan acara bersih Desa, serta 
merangkai sesaji yang diperuntukkan bagi leluhurnya. Kegiatan yang ke dua di kantor kelurahan dengan menyiapkan hidangan makanan yang dimakan saat selesai kirab.

Budaya nyadran ini wajib di lakukan bagi seorang kepala desa, dengan alasan nyadran sudah menjadi tradisi budaya yang selalu diturunkan ke generasi kepala desa berikutnya. Nyadran dilakukan di tiga tempat, yang pertama di punden desa, yang kedua di makam orang tua kepala desa apabila orang tuanya sudah meninggal, dan yang terakhir di sumber air yang pertama kali mengalirkan air ke desa yang ditempatinya. Pelaksana kegiatan hajatan ini ditunjuk bukan berdasarkan undangan namun merupakan partisipasi masyarakat yang siap membantu pelaksanaan selamatan desa. Kemudian hari berikutnya dilakukan bersih desa dengan melakukan kirab desa

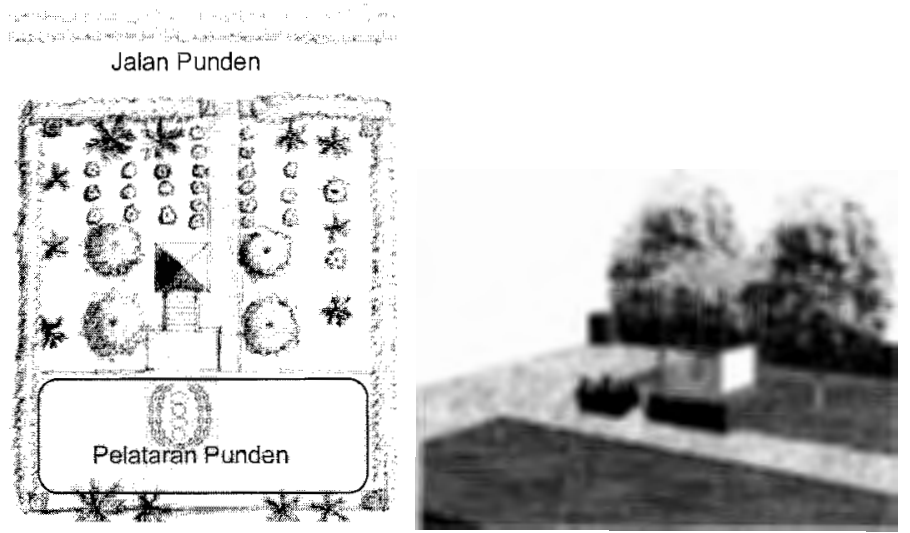

Gambar 4. Kegiatan nyadran di Punden

Sumber: Dokumentasi pribadi, 2011
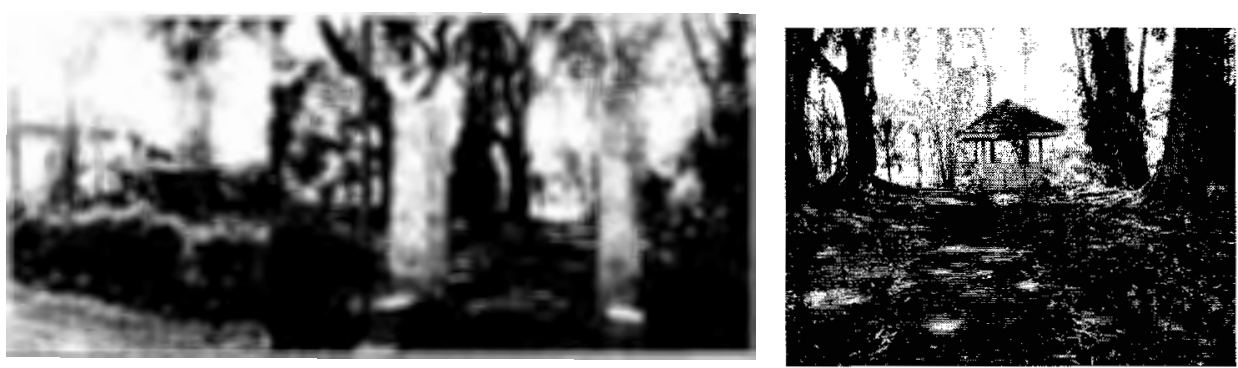

Gambar 5. Lokasi Kegiatan nyadran di Punden Desa

Sumber: Dokumentasi pribadi, 2011 


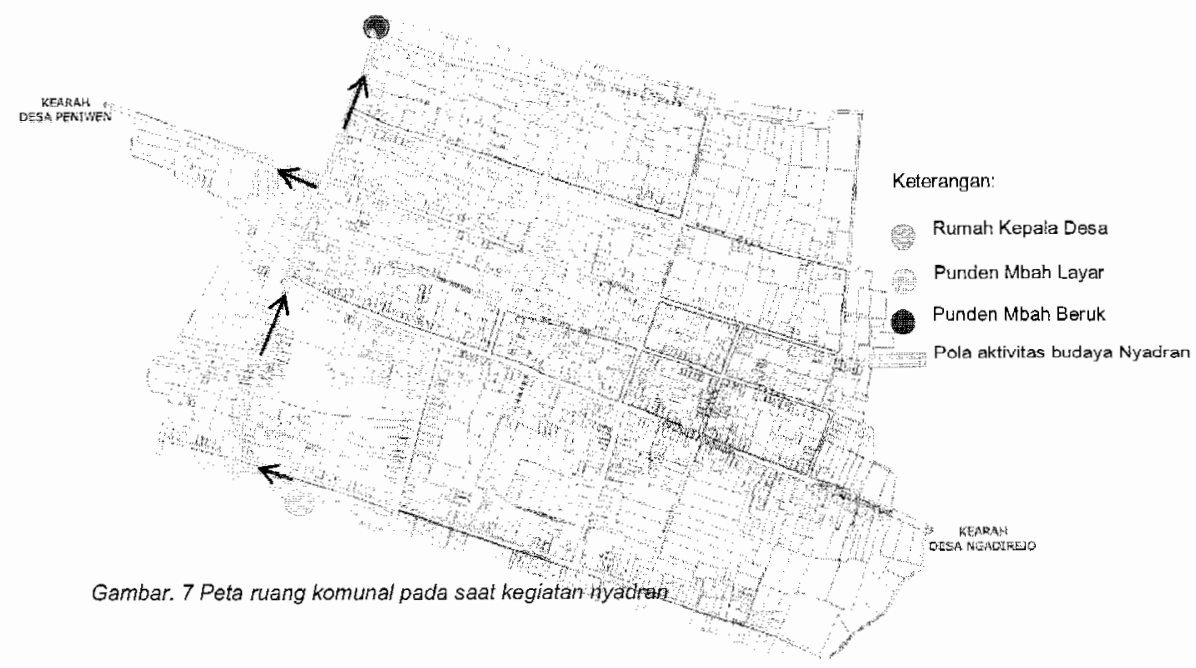

Gambar 6. Peta ruang komunal pada saat kegiatan nyadran Sumber: Dokumentasi pribadi, 2011

Fisik ruang aktivitas budaya warga Dukuh Krajan Desa Kromengan yang terbentuk adalah pada waktu nyadran, diawali dengan pembuatan sesaji di rumah kepala desa yang kemudian dibawa ke balai desa, kemudian ke punden, dan dilanjutkan ke makam desa serta ke sumber mata air yang mengaliri sungai di Dukuh Krajan.

\section{Kirab Desa dan pertunjukan wayang kulit}

Runtutan kegiatan yang ketiga adalah kegiatan kirab desa. Kirab desa ini dilakukan oleh masyarakat Dukuh Krajan setiap satu tahun sekali, dengan rute kirab yang mengalami perubahan di setiap tahunnya dan selalu bertempat di wilayah lingkungan RW. 05, 06 dan 07. Kegiatan ini diikuti oleh kesenian paguyuban berupa sogukan, reog, kuda lumping, serta kelompok petani dan pembuat jamu gendong dan juga siswa siswi mulai dari jenjang TK sampai SMA, masyarakat, perwakilan RT/RW serta perangkat desa. Aktivitas tahunan ini lebih banyak membentuk ruang bersama di lapangan Buk Petung, balai desa dan pinggir jalan halaman serta teras warga, lihat Gambar 7 dan Gambar 8 . 

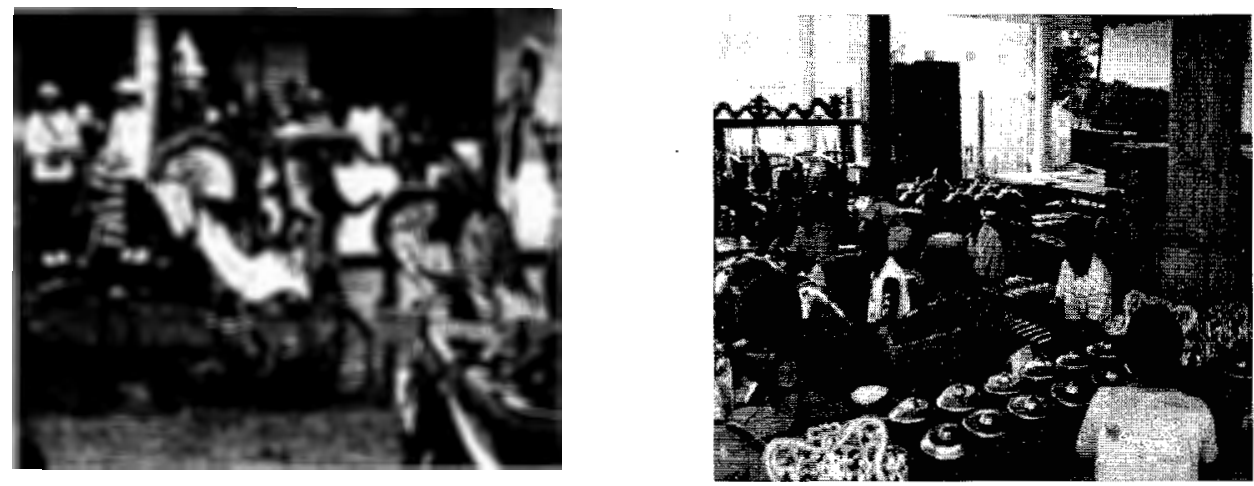

Gambar 7. Kirab Desa dan 8. Pertunjukan wayang di balai desa Sumber: Dokumentasi pribadi, 2011

Penutupan kirab Desa dilanjutkan dengan berkumpulnya para perangkat desa dan tokoh masyarakat untuk melantunkan tembang-tembang Jawa bersama sinden-sinden yang ditunjuk dan kemudian diakhiri dengan pagelaran wayang kulit semalam suntuk. Kegiatan ini dilakukan di pelataran dan pendopo kantor desa.

Pada waktu kegiatan kirab desa dimulai, masyarakat berkumpul di teras-teras rumah warga, halaman rumah warga dan jalanan. Menurut hasil pengamatan, sebagian warga menyiapkan tempat duduk kayu serta menyiapkan minuman bagi yang melakukan kirab atau penonton atau masyarakat yang menikmati jalannya kirab tersebut tanpa diminta ataupun disuruh, yang berarti merupakan kesadaran dari masing-masing warga sendiri, lihat Gambar 9, 10, 11, 12, dan 13 .
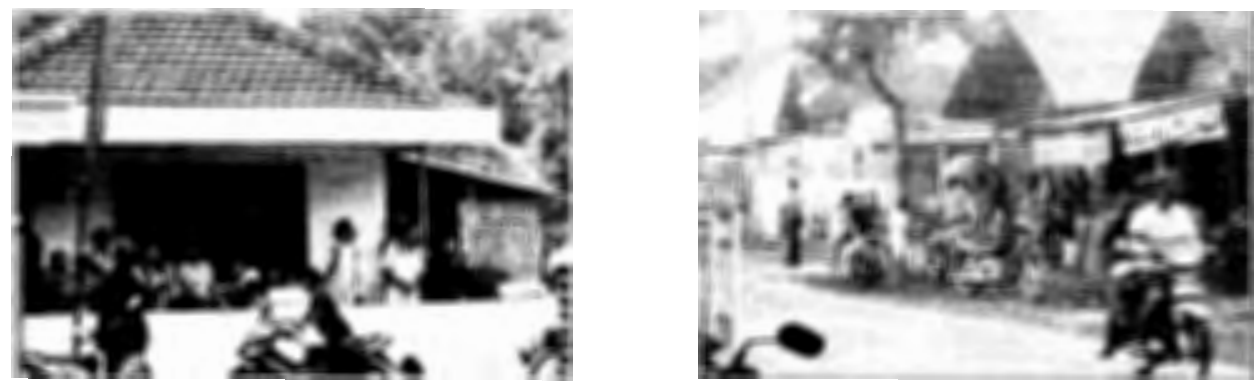

Gambar 9. Masyarakat memanfaatkan teras, halaman warga serta damija (daerah milik Jalan)

Sumber: Dokumentasi pribadi, 2011 

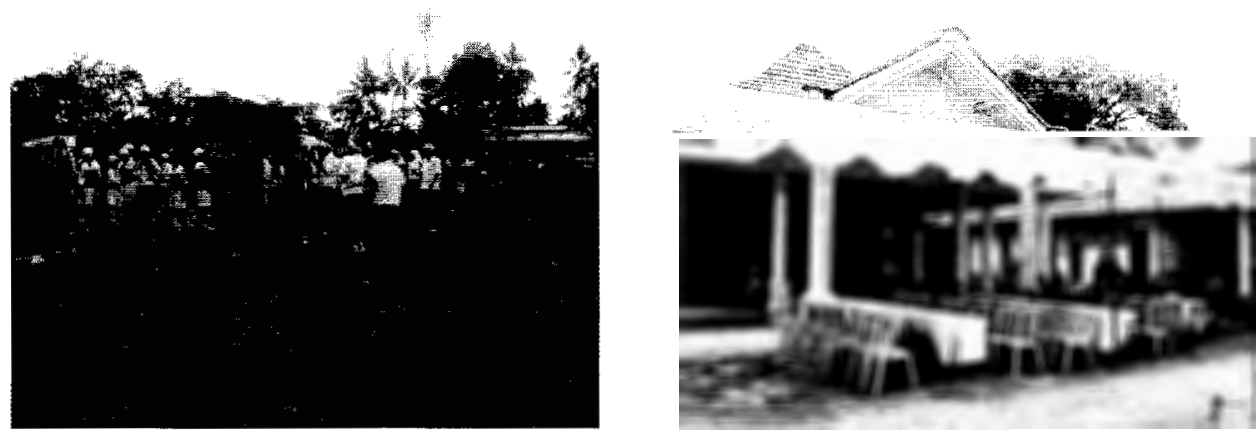

Gambar 10. Lapangan Buk Petung pada saat bersih desa. Gambar 11. Balai Desa pada saat bersih desa

Sumber: Dokumentasi pribadi, 2011
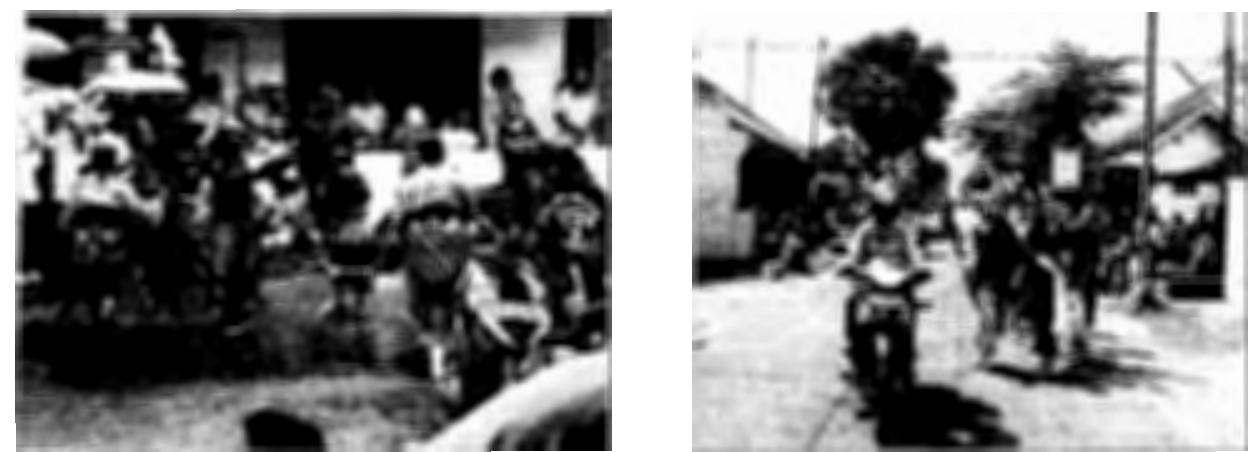

Gambar 12. Penggunaan jalan pada saat bersih desa. Gambar 13. Penggunaan jalan pada saat bersih desa

Sumber: Dokumentasi pribadi, 2011

Pada waktu kirab desa fisik ruang yang terbentuk diawali dari pusat komunal masing-masing peserta menuju lapangan Buk Petung milik desa. Setelah semuanya berkumpul di lapangan, maka kirab dimulai dengan mengikuti rute kirab yang sudah ditentukan dengan mengelilingi wilayah RW. 05, 06 dan 07. Kemudian berakhir di balai desa yang berada di sebelah barat wilayah Desa Kromengan, lihat Gambar 14 dan Gambar 15. 


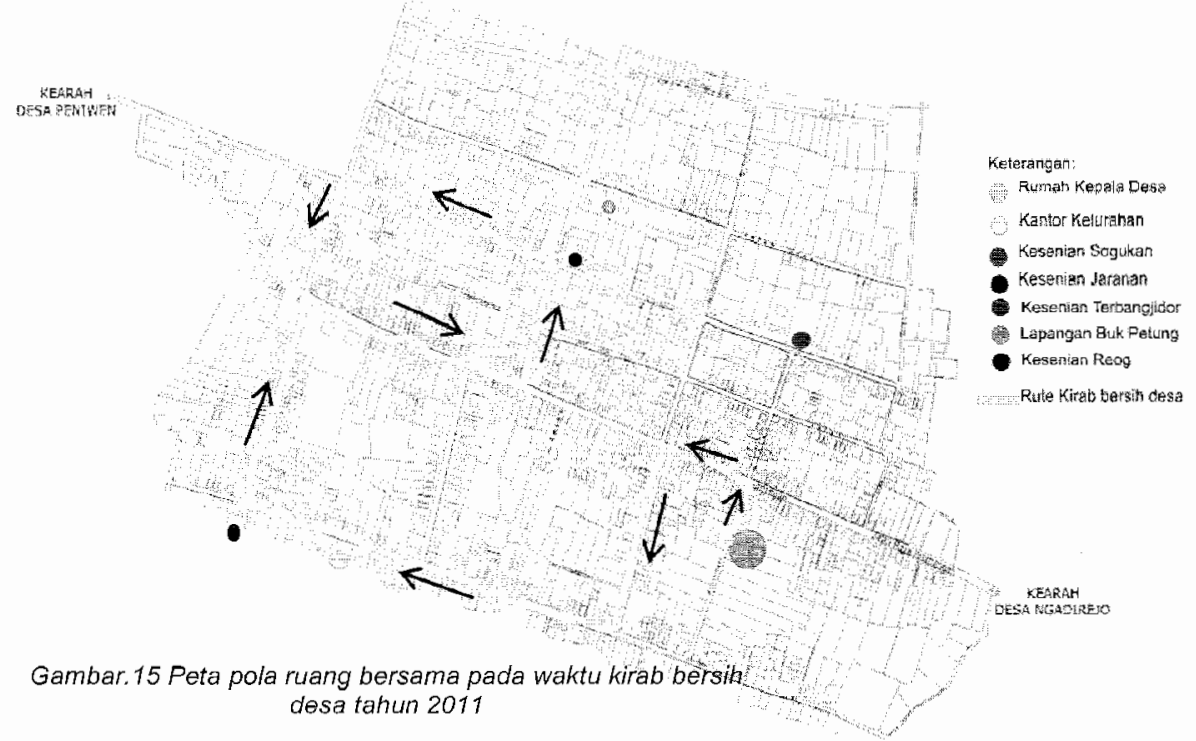

Gambar 14. Peta pola ruang bersama pada waktu kirab bersih desa tahun 2011 Sumber: KPP Pratama Kepanjen, 2008

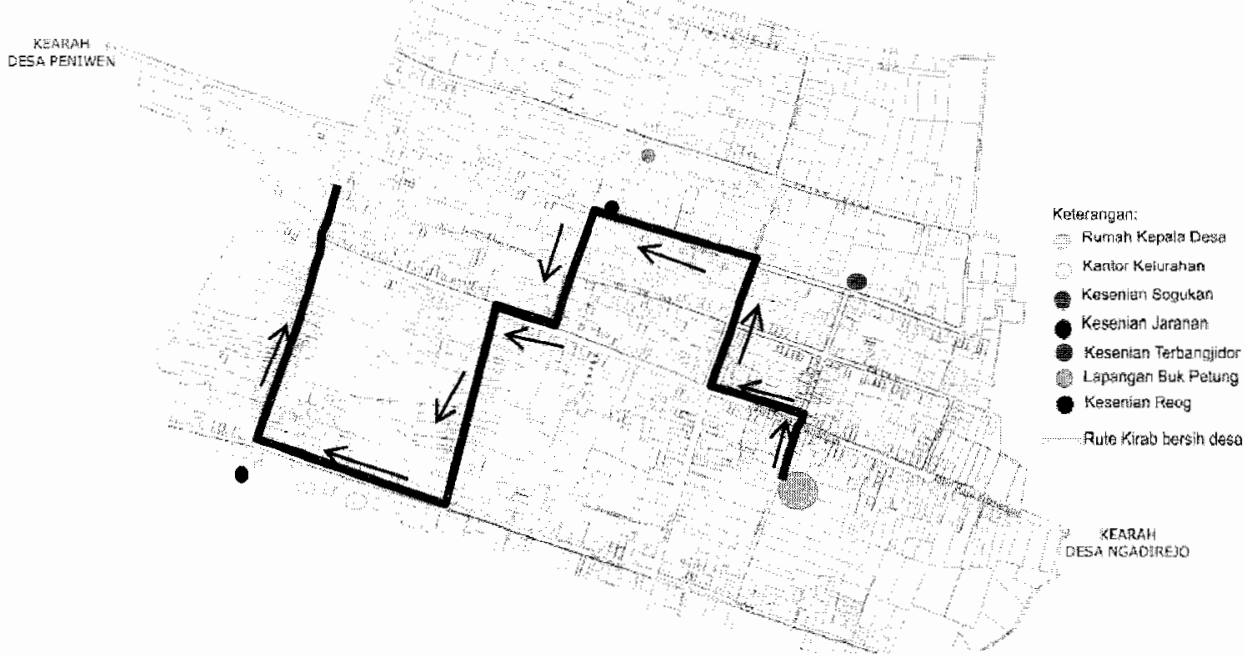

Gambar 15. Peta pola ruang bersama pada waktu kirab bersih desa tahun 2012 Sumber: KPP Pratama Kepanjen, 2008 


\section{Pengajian Tahunan}

Runtutan yang terakhir adalah pengajian tahunan. Pengajian ini bertempat di balai desa tepatnya di pendopo yang diikuti oleh semua warga Desa Kromengan. Ruang-ruang yang terbentuk adalah pendopo desa, halaman serta ruang kerja kantor desa yang digunakan untuk menyiapkan semua keperluan pengajian tersebut, selain itu juga jalan depan kantor desa termanfaatkan sebagai ruang bersama, untuk tempat parkir anggota pengajian. dan tempat berjualan, lihat Gambar 16, 17, dan 18.
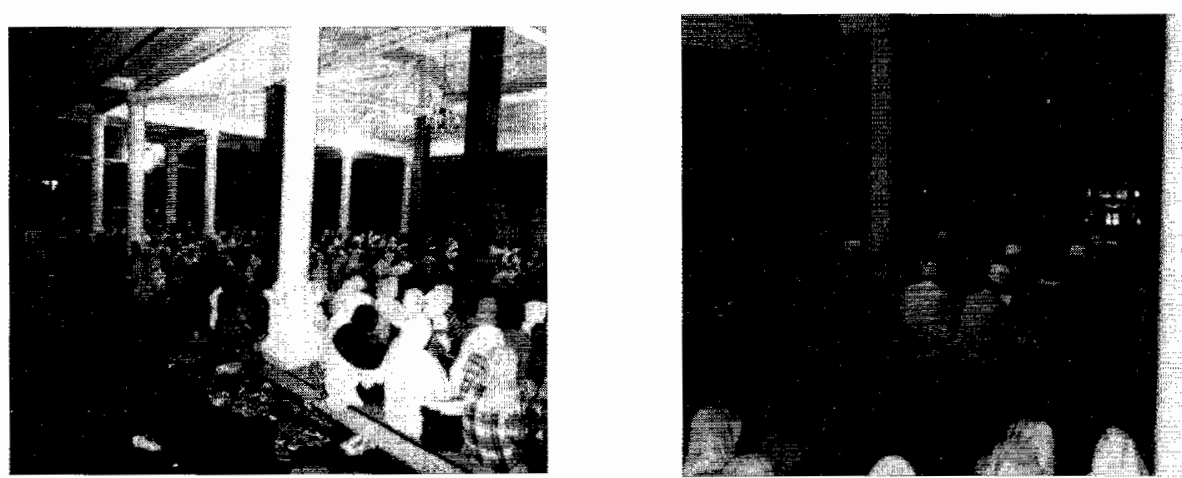

Gambar 16. Pengajian Tahunan. Gambar 17. Kelompok Terbangan Sumber: Dokumentasi Pribadi, 2011

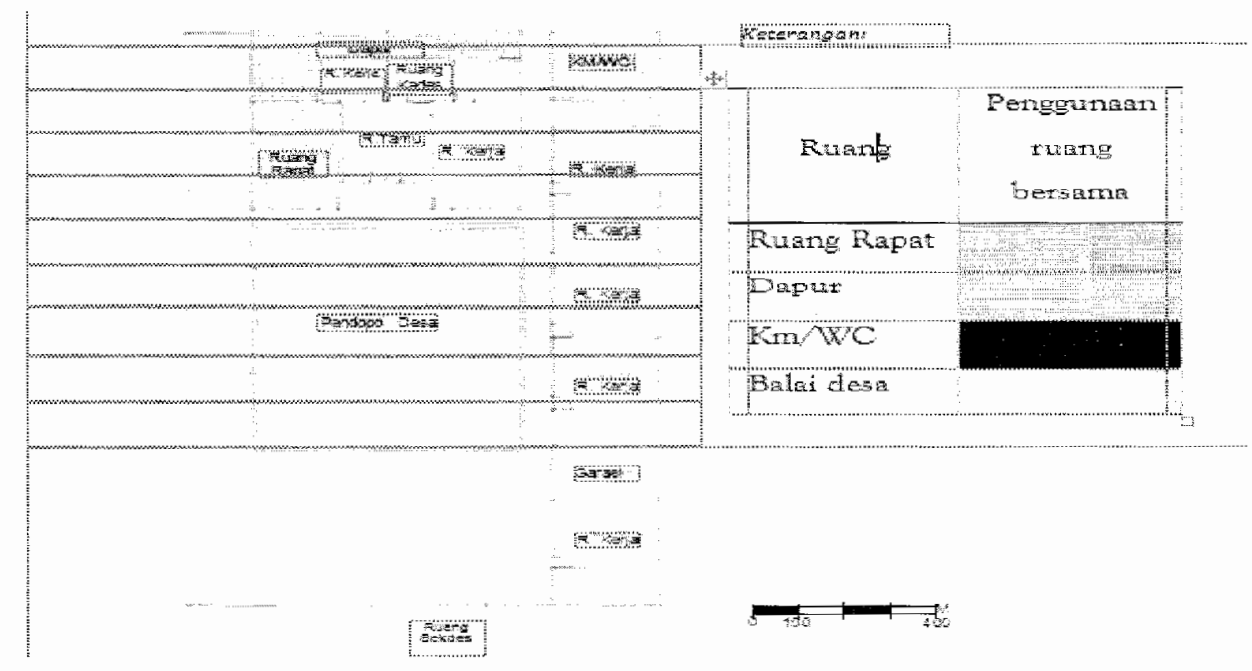

Gambar 18. Pendopo tempat pengajian tahunan

Sumber: Dokumen Pribadi, 2011 
Dari keseluruhan runtutan kegiatan budaya nyadran, kegiatan ini lebih banyak menggunakan fasilitas umum dalam pelaksanaannya. Fasilitas umum bukan menjadi magnet melainkan menjadi ruang komunal. Dalam kegiatan nyadran ini intensitas pemanfaatan ruangnya relatif rendah dan jarak jangkauan dari hunian relatif jauh disebabkan karena tiap masing-masing rumah memiliki halaman yang cukup luas.

Permasalahan sosial yang sudah mulai berkembang saat ini yang menyebabkan semakin lunturnya semangat gotong royong, dan semakin hilangnya tradisi budaya setempat. Kegiatan budaya nyadran yang ada di Dukuh Krajan sangat bermanfaat, selain untuk mempertahankan tradisi budaya setempat juga dapat menciptakan pola-pola penggunaan ruang komunal yang sifatnya untuk kebersamaan dan keguyuban antar warga.

\section{Simpulan}

Ruang komunal merupakan ruang bersama yang terbentuk atas dasar partisipasi warga. Dalam kehidupan pedesaan ruang komunal ditumbuhkan melalui kebersamaan dalam berbagai kegiatan baik sosial maupun budaya yang bertujuan untuk kepentingan bersama. Kebersamaan dalam hal ini dapat mengurangi dampak pada perubahan sosial yang menyebabkan adanya beberapa budaya lokal yang tersisihkan atau masalah-masalah sosial yang sudah mulai berkembang di wilayah pedesaan. Dari paparan di atas dapat disimpulkan bahwa pembentukan ruang komunal dipengaruhi oleh aktivitas itu sendiri, fisik ruang, pelaku dan waktu kegiatan itu berlangsung. Runtutan kegiatan budaya nyadran ini memiliki suatu makna yaitu kebersamaan dan keguyuban. Penggunaan ruang komunal pada kegiatan budaya nyadran terbentuk juga ketika muncul rasa kepedulian yang tinggi terhadap lingkungannya, adanya kesadaran masyarakat dalam memberikan sebagian ruang miliknya yang bermanfaat untuk kepentingan umum.

\section{Daftar Pustaka}

Bintarto, R., 1989, Interaksi Desa dan Kota dan Permasalahannya. Jakarta: Ghalia Indonesia

Robinson, Julia W. 2001, Institutional Space, Domestic Space, and Power Relations: Revisiting territoriality with space syntax. 3rd International Space Syntax Symposium Atlanta.

Rencana Pembangunan Jangka Menengah Desa (RPJMD), 2010-2014 Desa 
Kromengan

De-kill. 2009, http://de-kill.blogspot.com/2009/04/tradisi-nyadran-masyarakat-jawa.html (14 April 2009)

Adipawira. T., 2011, http://tumija.wordpress.com/2011/03/15/globalisasi/ (15 Maret 2011) 